\title{
MINUMAN SIRUP LIMBAH SARI MENGKUDU (Morinda citrifolia L.)
}

\section{BEVERAGES WASTE EXTRACT OF MENGKUDU (Morinda citrifolia L.)}

\author{
R Yuliana ${ }^{1}$, SI Rahmawati1a, dan N Novidahlia' \\ ${ }^{1}$ Jurusan Ilmu Pangan Halal, Fakultas Ilmu Pangan Halal, Universitas Djuanda Bogor \\ Jl. Tol Ciawi No. 1, Kotak Pos 35 Ciawi, Bogor 16720. \\ a Korespondensi: Siti Irma Rahmawati, E-mail: siti.irma.rahmawati@unida.ac.id \\ (Diterima: 29-08-2017; Ditelaah: 30-08-2017; Disetujui: 29-10-2017)
}

\begin{abstract}
Mengkudu (Morinda citrifolia L.) efficacious to treat some degenerative diseases such as cancer, tumors, and diabetes. In general, the utilization of mengkuduis limited only for juice, while the other parts have not been optimally utilized. The purpose of this research is to know the effect of honey concentration on organoleptic characteristic of mengkudu juice syrup, to find out the formulation of mengkudu juice syrup, and to know the content of vitamin C, antioxidant and microbial levels of selected mengkudu juice syrup. mengkudu juice syrup is made with three kinds of comparison from honey and water, with different ratio which are; 50\%: 50\%, 60\%: 40\%, and $70 \%: 30 \%$ with two replications. The analysis included organoleptic (sensory quality test and hedonic test), physical (viscosity), and chemical analysis (antioxidant and vitamin C), microbial (Total Plate Count) test for the most preferred syrup. The most preferred noni syrup is the syrup with $70 \%$ honey and 30\% water, which has an antioxidant level of 859 IC50 (rpm), vitamin C level of 15,53\%, and Total Plate Count (TPC) of $175 \mathrm{CFU} / \mathrm{mL}$.
\end{abstract}

Keywords: mengkudu, syrup, vitamin C, antioxidant, Total Plate Count (TPC).

\section{ABSTRAK}

Buah Mengkudu (Morinda citrifolia L.) berkhasiat untuk mengobati beberapa penyakit degeneratif seperti kanker, tumor, dan diabetes.Pada umumnya pemanfaatan mengkudu baru terbatas pada sari buahnya saja sedangkan bagian yang lain belum dimanfaatkan secara optimal. Tujuan penelitianini adalah mengetahui pengaruh konsentrasi madu terhadap sifat organoleptik sirup limbah sari mengkudu, mengetahui formulasi sirup limbah sari mengkudu, dan mengetahui kandungan vitamin C, kadar antioksidan, dan mikroba pada sirup limbah sari mengkudu yang sudah terpilih. Sirup limbah sari mengkudu dibuat dengan tiga perbandingan madu dan air yaitu 50\%:50\%, 60\%:40\%, dan 70\%:30\%dengan dua kali ulangan. Analisis yang dilakukan meliputi organoleptik (uji mutu sensori dan uji hedonik), fisik (kekentalan), dananalisis kimia (antioksidan dan vitamin C), uji mikroba (Total Plate Count) untuk sirup yang paling disukai. Sirup limbah sari mengkudu yang disukai adalah sirup dengan perbandingan madu 70\% dan air 30\%, memiliki nilai antioksidan 859 IC50(rpm), kadar vitamin C sebesar 15,53\%, dan Total Plate Count (TPC) sebesar 175 CFU/mL.

Kata kunci: mengkudu, sirup, vitamin C, antioksidan, Total Plate Count (TPC).

Yuliana R, SI Rahmawati, dan N Novidahlia. 2017. Minuman Sirup Limbah Sari Mengkudu (Morinda Citrifolia L.). Jurnal Pertanian 8(2): 121-129. 


\section{PENDAHULUAN}

Tanaman mengkudu dikenal juga sebagai tanaman obat. Tanaman ini merupakan tumbuhan perdu yang berasal dari daerah Tahiti dan Hawaii. Masyarakat tradisional Hawaii mengkonsumsi sari buah mengkudu dengan terlebih dahulu melakukan fermentasi secara spontan. Akhir-akhir ini buah mengkudu telah banyak diolah menjadi berbagai macam jenis produk seperti sari buah (tanpa fermentasi), tablet, dan kapsul yang dipromosikan sebagai minuman atau makanan kesehatan (Hardoko dkk., 2003).

Beberapa tahun terakhir, tanaman mengkudu (Morinda citrifolia L.) mendapat perhatian dari masyarakat karena adanya fakta empiris serta bukti penelitian ilmiah yang menyatakan bahwa "Buah mengkudu berkhasiat untuk mengobati beberapa penyakit degeneratif seperti kanker, tumor, dan diabetes". Beberapa jenis senyawa berkhasiat obat yang sudah diketahui dalam buah mengkudu antara lain antraquinone (peremajaan sel), damnacanthal (pencegah perkembangan sel kanker), xeronin, proxeronin, dan lain-lain (Winarti, 2005).

Pemanfaatan buah mengkudu sebagai bahan baku industri pangan dan non pangan telah banyak dilakukan. Pada umumnya pemanfaatan mengkudu baru terbatas pada sari buahnya saja sedangkan bagian yang lain belum dimanfaatkan secara optimal (Raharja, 2004). Pembuatan sari buah mengkudu dengan cara pencucian buah mengkudu, kemudian didiamkan selama 3 hari, diambil cairannya dengan cara disaring (Amar, 2002). Produksi sari buah mengkudu yang semakin meningkat menghasilkan limbah/ampas hasil pengolahan mengkudu yang semakin banyak. Limbah/ampas yang dihasilkan dari produksi sari buah mengkudu adalah berupa kulit buah, biji dan daging buah mengkudu. Ampas mengkudu selama ini hanya dibuang tanpa dimanfaatkan lebih lanjut.

Padahal, Purwadaria dalam Bintang (2007) melaporkan bahwa ampas mengkudu hasil perasan sari buah mengkudu masih mengandung zat bioaktif seperti polifenol dan saponin. Senyawa polifenol dan saponin tersebut bersifat antibakteri, senyawa polifenol banyak terdapat dalam tanaman obat-obatan. Ampas mengkudu juga merupakan limbah yang mempunyai fraksi serat yang sangat bermanfaat bagi kesehatan manusia.Zat bioaktif pada ampas mengkudu bersifat anti bakteri, membunuh bakteri pathogen.

Permasalahan utama buah mengkudu adalah aromanya yang tidak enak. Hasil samping sari mengkudu yang dihasilkan juga masih menghasilkan bau yang tidak enak. Bau tidak enak tersebut dapat dihilangkan dengan penambahan rasa dan perisa. Oleh karena itu diharapkan adanya produk olahan dari limbah mengkudu yang mempunyai khasiat yang bagus seperti sirup.

Sirup adalah minuman ringan yang berupa larutan kental dengan cita rasa beranekaragam. Berbeda dengan sari buah, sirup dikonsumsi tidak langsung diminum tetapi harus diencerkan terlebih dahulu. Pengenceran diperlukan sebab kandungan gulanya tinggi, sekitar 65 persen. Pada dasarnya, sirup terbuat dari bahan dasar gula yang kental dan untuk menambah rasa sering disertai penambah rasa, pewarna, asam sitrat, asam tatrat, atau asam laktat (Ariesta, 2012).

Pada penelitian ini, gula yang digunakan untuk membuat sirup diganti dengan menggunakan madu. Secara umum madu berkhasiat sebagai penghasil energi, untuk meningkatkan daya tahan tubuh, serta meningkatkan stamina. Banyak penyakit yang dapat disembuhkan dengan mengkonsumsi madu diantaranya penyakit lambung, radang usus, jantung dan hipertensi. Selain itu, pada madu terdapat zat asetil kolin yang berfungsi untuk melancarkan metabolisme seperti memperlancar peredaran darah dan menurunkan tekanan darah. Tujuan dari penelitian ini adalah untuk membuat produk sirup dari hasil samping sari mengkudu dan mengetahui kandungan gizi yang terdapat dalam limbah sari mengkudu dan sirup. Olahan sirup mengkudu belum banyak dikenal oleh masyarakat Indonesia, sehingga sirup mengkudu akan menjadi trobosan baru pada produk minuman fungsional dan dapat meningkatkan nilai guna buah, terutama pada pemanfaaatan limbah mengkudu. 


\section{MATERI DAN METODE}

\section{Bahan dan Alat Penelitian}

Bahan-bahan yang digunakan dalam penelitian ini adalah hasil samping sari mengkudu, air mineral, jahe, madu, media plate count agar, amilum $1 \%$, iodium $0,01 \mathrm{~N}$, aquadest dan bahan kimia lainnya sebagai bahan pendukung dalam pengujian kimia dan pengujian mikroba.

Alat yang digunakan dalam penelitian ini adalah viskometer Brookfield, termometer digital , timbangan digital, baskom, pisau, sendok, talenan, pisau, sendok, stopwatch, dan alat kimia lainya sebagai bahan pendukung dalam pengujian kimia dan pengujian mikroba.

\section{Tempat dan Waktu Penelitian}

Penelitian dilaksanakan di laboratorium PT Mutuagung Lestari, Depok dan LPPM IPB, Bogor. Penelitian dilaksanakan bulan Juni Agustus 2017.

\section{Metode Penelitian}

Tujuan penelitian ini untuk pembuatan sirup hasil samping sari buah mengkudu. Tahap pembuatan sirup ini pertama yaitu hasil samping sari mengkudu ditimbang sebanyak 500 gram. Hasil samping sari mengkudu dihancurkan atau diblender dengan penambahan air dengan berbagai konsentrasi (50\% air, 40\% air, dan 30\% air), kemudian di saring. Hasil samping sari mengkudu ditambahkan air jahe $50 \mathrm{~mL}$ dan madu dengan berbagai konsentrasi (50\% madu, 60\% madu, dan 70\% madu). Setelah itu direbus dan diaduk pada suhu $100 \mathrm{oC}$ selama 20 menit. Setelah itu sirup limbah mengkudu dimasukan ke dalam botol yang sudah disterilkan yaitu dengan perebusan botol selama 15 menit. Botol yang digunakan adalah botol kaca. Kemudian dilakukan uji organoleptik yaitu uji mutu sensori dan uji hedonik, dan juga uji fisik yaitu uji kekentalan (viskositas). Produk yang terpilih (produk yang disukai panelis) akan dilanjutkan ke uji antioksidan, vitamin $\mathrm{C}$, dan Total Plate Count (TPC). Komposisi bahan dalam pembuatan sirup hasil samping sari buah mengkudu dapat dilihat pada Tabel 1.

Tabel 1 Komposisi bahan pembuatan sirup hasil samping sari buah mengkudu

\begin{tabular}{llll}
\hline \multirow{2}{*}{ Bahan } & \multicolumn{3}{l}{ Komposisi Bahan } \\
\cline { 2 - 4 } & A1 & A2 & A3 \\
\hline $\begin{array}{l}\text { Hasil Samping } \\
\text { Sari }\end{array}$ & $500 \mathrm{~g}$ & $500 \mathrm{~g}$ & $500 \mathrm{~g}$ \\
Mengkudu & & & \\
Madu & $500 \mathrm{~mL}$ & $600 \mathrm{~mL}$ & $700 \mathrm{~mL}$ \\
Air & $500 \mathrm{~mL}$ & $400 \mathrm{~mL}$ & $300 \mathrm{~mL}$ \\
Air Jahe & $50 \mathrm{~mL}$ & $50 \mathrm{~mL}$ & $50 \mathrm{~mL}$ \\
\hline
\end{tabular}

\section{Rancangan Percobaan}

Rancangan percobaan yang digunakan dalam penelitian ini yaitu Rancangan Acak Lengkap (RAL) Satu Faktor dengan pengulangan sebanyak dua kali. Percobaan ini menggunakan satu faktor yaitu perbandingan madu dan air dan tiga taraf perlakuan, yaitu:

A1= Madu (50\%) : Air (50\%)

A2 $=$ Madu (60\%) : Air (40\%)

A3 = Madu (70\%) : Air (30\%) Persamaan model linear aditif

Rancangan percobaan adalah sebagai berikut.

$$
\boldsymbol{Y}_{i j}=\mu+A_{i}+\varepsilon_{i j}
$$

Keterangan: $Y_{i j}=$ Pengamatan pada perlakuan ke-i dan ulangan ke-j; $\mu$ = Rataan umum; $A_{i}=$ Pengaruh perlakuan madu dan air pada taraf ke-I; $\varepsilon \mathrm{ij}=$ Pengaruh acak pada perlakuan ke-i dan ulangan ke-j; i = 1, 2, 3; j = 1, 2 .

\section{Analisis Produk}

Produk sirup limbah mengkudu yang dihasilkan akan dilakukan uji organoleptik dan uji fisik. Uji organoleptik meliputi uji mutu sensori dan uji hedonik, sedangkan uji fisik meliputi uji kekentalan (viskositas). Uji mutu sensori menggunakan skala garis 0$10 \mathrm{~cm}$ dengan parameter uji warna, rasa, aroma, dan kekentalan dengan jumlah panelis sebanyak 30 orang. Uji hedonik dengan skala numerik yaitu 1-7 dengan parameter uji warna, rasa, aroma, dan kekentalan dengan jumlah panelis sebanyak 30 orang. Uji fisik dengan uji kekentalan (viskositas) metode Brookfield. Sirup mengkudu yang terpilih akan 
dilakukan uji antioksidan metode DPPH, uji vitamin $\mathrm{C}$, dan juga dilakukan pengujian mikroba Total Plate Count (TPC).

\section{Analisis Data}

\section{Uji Mutu Sensori}

Data yang diperoleh dianalisa secara statistik dengan menggunakan menggunakan Analysis of Variance (ANOVA) dengan bantuan programSPSS Statistics 17.0 untuk mengetahui pengaruh warna, aroma, rasa, dan tekstur (kekentalan) yang dilakukan pada penelitian ini. Jika hasil yang diperoleh dari uji sidik ragam ANOVA $\mu<\alpha$ (berpengaruh nyata), maka perlu diuji lanjut nilai tengah perlakuan dengan Duncan Multiple Range Test (DMRT) untuk mengetahui perbedaan pengaruh perlakuan. Tingkat kepercayaan atau significance level yang digunakan yaitu 95\% (taraf $\alpha=0,05$ ).

\section{Uji Hedonik}

Data yang diperoleh dianalisa secara statistik dengan menggunakan SPSS Statistik 17.0 uji non parametrik (kruskal wallish) untuk mengetahui ada atau tidak perbedaan penilaian yang dilakukan responden terhadap rata-rata nilai parameter (rasa, warma, aroma, dan kekentalan). Jika hasil yang diperoleh dari uji sidik ragam kruskal wallish $p>\alpha$ (ada perbedaan) maka perlu diuji lanjut U Mann-Whitney untuk mengetahui perlakuan mana yang berbeda

\section{HASIL DAN PEMBAHASAN}

\section{Analisis Organoleptik (Uji Mutu Sensori dan Uji Hedonik)}

Pada uji mutu sensori panelis diminta untuk mengisi form uji yang telah disediakan dengan nilai yang diberikan adalah 0-10 cm dengan parameter rasa, warna, aroma, dan tekstur (kekentalan). Rekapulasi rata-rata hasil uji mutu sirup limbah sari mengkudu parameter rasa, aroma, warna, dan tekstur (kekentalan) dapat dilihat pada Tabel 2.
Tabel 2 Rekapitulasi rata-rata hasil uji mutu sirup hasil samping sari mengkudu parameter rasa, aroma, warna, dan tekstur (kekentalan).

\begin{tabular}{lrrr}
\hline \multirow{2}{*}{ Parameter } & \multicolumn{3}{c}{ Perlakuan } \\
\cline { 2 - 4 } & \multicolumn{1}{c}{ A1 } & \multicolumn{1}{c}{ A2 } & \multicolumn{1}{c}{ A3 } \\
\hline Rasa & $5,81 \mathrm{a}$ & $5,26 \mathrm{~b}$ & $4,38 \mathrm{c}$ \\
Warna & $5,11 \mathrm{a}$ & $5,30 \mathrm{a}$ & $5,25 \mathrm{a}$ \\
Aroma & $5,68 \mathrm{a}$ & $5,25 \mathrm{~b}$ & $4,80 \mathrm{c}$ \\
Tekstur & $5,36 \mathrm{a}$ & $5,62 \mathrm{a}$ & $5,51 \mathrm{a}$ \\
(kekentalan & & & \\
\cline { 2 - 4 } & & &
\end{tabular}

Keterangan: Notasi huruf berbeda pada baris yang sama menunjukkan berbeda nyata pada $\alpha=0,05$

Sirup limbah sari buah mengkudu, dilakukan uji organoleptikyaitu uji hedonik dengan tujuh skala antara lain (1) sangat tidak suka, (2) tidak suka, (3) agak tidak suka, (4) biasa, (5) agak suka, (6) suka dan (7) sangat suka. Setelah itu, data hasil uji hedonik dianalisis dengan uji kruskal wallis.

Parameter organoleptik yang diujikan adalah rasa, aroma, warna dan tekstur (kekentalan). Rekapulasi rata-rata hasil uji mutu sirup parameter rasa, aroma, warna, dan tekstur (kekentalan) dapat dilihat pada Tabel 3.

Tabel 3 Rekapitulasi rata-rata hasil uji hedonik sirup hasil samping sari mengkudu parameter rasa, aroma, warna, dan tekstur (kekentalan)

\begin{tabular}{lrrr}
\hline \multirow{2}{*}{ Parameter } & \multicolumn{3}{c}{ Perlakuan } \\
\cline { 2 - 4 } & A1 & A2 & A3 \\
\hline Rasa & $3,70 \mathrm{a}$ & $4,60 \mathrm{~b}$ & $5,23 \mathrm{c}$ \\
Warna & $4,57 \mathrm{a}$ & $4,70 \mathrm{a}$ & $4,47 \mathrm{a}$ \\
Aroma & $4,57 \mathrm{a}$ & $4,57 \mathrm{a}$ & $4,57 \mathrm{a}$ \\
Tekstur & $4,67 \mathrm{a}$ & $4,83 \mathrm{a}$ & $4,83 \mathrm{a}$ \\
(Kekentalan) & & & \\
\hline
\end{tabular}

Keterangan: Notasi huruf berbeda pada baris yang sama menunjukkan berbeda nyata pada $\alpha=0,05$

\section{Rasa}

Nilai rata-rata panelis menilai mutu rasa sirup berkisar antara 4,38-5,81 dari sedikit asam sampai degan menuju sangat asam. Berdasarkan analisa sidik ragam (ANOVA) menunjukkan bahwa perbedaan perlakuan perbandingan madu dan air berpengaruh nyata terhadap mutu rasa sirup limbah sari mengkudu. Berdasarkan uji lanjut Duncan 
diketahui bahwa mutu rasa sirup limbah pada perlakuan A1 (madu 50\% : Air 50\%) berbeda nyata dengan perlakuan A2 (madu 60\% : Air 40\%), dan A3 (madu 70\% : air 30\%).

Perbedaan perlakuan dari perbandingan madu dan air berbeda nyata terhadap parameter rasa sirup. Berdasarkan uji lanjut man whitney diketahui bahwa tingkat kesukaan panelis terhadap rasa sirup pada perlakuan A1 (madu 50\% : Air 50\%) berbeda nyata dengan perlakuan A2 (madu 60\% : Air 40\%), dan A3 (madu 70\% : air 30\%). Tingkat kesukaan A1 (madu 50\% : Air 50\%) yaitu 3,70(agak suka), tingkat kesukaan A2 (madu 60\% : Air 40\%) yaitu 4,60 (netral), dan tingkat kesukaan A3 (madu 70\% : Air 30\%) yaitu 5,23 (netral).

Faktor yang berpengaruh terhadap rasa sirup adalah perbandingan madu dengan air. Pada uji mutu sensori panelis menilai sirup yang mengandung banyak madu lebih sedikit asam, sedangkan sirup yang mengandung sedikit madu rasanya lebih menuju ke rasa asam. Pada uji hedonik sirup, menyatakan semakin meningkat penambahan madu semakin meningkat nilai kesukaan panelis. Hal ini disebabkan karena panelis merasakan semakin banyak madu yang ditambahkan rasa asam dari hasil samping buah mengkudu berkurang. Penambahan madu yang lebih banyak membentuk keseimbangan yang lebih baik dengan keasaman yang diperoleh dari hasil sampingsari mengkudu, sehingga sirup limbah sari mengkudu lebih disukai panelis.

\section{Warna}

Nilai rata-rata panelis menilai mutu rasa sirup berkisar antara 5,11-5,25 dari kuning muda sampai degan menuju kuning kecoklatan. Berdasarkan analisa sidik ragam (ANOVA) menunjukkan bahwa perbedaan perlakuan perbandingan madu dan air tidak berpengaruh nyata terhadap mutu rasa sirup limbah sari mengkudu. Warna sirup ketiga perlakuan A1 (madu 50\% : Air 50\%), A2 (madu 60\% : Air 40\%), dan A3 (madu 70\% : air 30\%) menuju kearah kuning kecoklatan.

Perbedaan perlakuan dari perbandingan madu dan air tidak berbeda nyata terhadap parameter warna sirup. Berdasarkan uji lanjut man whitney diketahui bahwa tingkat kesukaan panelis terhadap warna sirup pada perlakuan A1 (madu 50\% : Air 50\%) tidak berbeda nyata dengan perlakuan A2 (madu 60\% : Air 40\%), dan A3 (madu 70\% : air 30\%). Tingkat kesukaan A1 (madu 50\% : Air 50\%) yaitu 4,57 (netral), tingkat kesukaan A2 (madu 60\% : Air 40\%) yaitu 4,70(netral), dan tingkat kesukaan A3 (madu 70\% : Air 30\%) yaitu 4,47(netral).

Faktor yang sangat berpengaruh pada warna sirup adalah konsentrasi madu yang ditambahkan. Panelis menyatakan tidak ada perbedaan nyata terhadap parameter warna ini baik secara uji mutu sensori dan uji hedonik. Warna yang dihasilkan hampir sama, hal ini karena warna yang dihasilkan sebagian besar dari warna madu yang ditambahkan yaitu kuning kecoklatan dan madu yang ditambahkan konsentrasinya tidak terlalu berbeda jauh yaitu 50\%, 60\%, dan 70\% hal ini juga menyebabkan warna tidak berbeda nyata pada sirup.

\section{Aroma}

Nilai rata-rata panelis menilai mutu rasa sirup berkisar antara 4,80-5,68 dari sedikit berbau sampai degan menuju berbau menyengat. Berdasarkan analisa sidik ragam (ANOVA) menunjukkan bahwa perbedaan perlakuan perbandingan madu dan air berpengaruh nyata terhadap mutu rasa sirup. Berdasarkan uji lanjut Duncan diketahui bahwa mutu rasa sirup limbah pada perlakuan A1 (madu 50\% : Air 50\%) berbeda nyata dengan perlakuan A2 (madu 60\% : Air 40\%), dan A3 (madu 70\% : air 30\%).

Perbedaan perlakuan dari perbandingan madu dan air tidak berbeda nyata terhadap parameter aroma sirup limbah sari mengkudu. Berdasarkan uji lanjut man whitney diketahui bahwa tingkat kesukaan panelis terhadap aroma sirup pada perlakuan A1 (madu 50\% : Air 50\%) tidak berbeda nyata dengan perlakuan A2 (madu 60\% : Air 40\%), dan A3 (madu 70\% : air 30\%). Tingkat kesukaan A1 (madu 50\% : Air 50\%) yaitu 4,57 (netral), tingkat kesukaan A2 (madu 60\% : Air 40\%) yaitu 4,57 (netral), dan tingkat kesukaan A3 (madu 70\% : Air 30\%) yaitu 4,57 (netral). 
Aroma yang dihasilkan dari ketiga sirup adalah aroma mengkudu yang difermentasi. Faktor yang sangat berpengaruh pada aroma sirup adalah penambahan air jahe dan penambahan madu. Penambahan air jahe dapat mengurangi aroma dari limbah sari buah mengkudu yang menyengat. Konsentrasi madu yang ditambahkan berbeda menyebabkan aroma sirup dengan penambahan madu yang banyak membuat sirup lebih tercium aroma madu dibandingkan aroma mengkudu yang telah difermentasi. Aroma yang dihasilkan memiliki aroma yang hampir sama karena senyawa volatil yang ada pada hasil samping sari buah mengkudu telah menguap, penambahan air jahe yang seimbang, dan penambahan madu yang tidak terlalu berbeda.

\section{Tekstur (Kekentalan)}

Nilai rata-rata panelis menilai mutu rasa sirup limbah sari mengkudu berkisar antara 5,365,62 dari cair sampai degan menuju sangat kental. Berdasarkan analisa sidik ragam (ANOVA) menunjukkan bahwa perbedaan perlakuan perbandingan madu dan air tidak berpengaruh nyata terhadap mutu rasa sirup limbah sari mengkudu. Kekentalan sirup ketiga perlakuan A1 (madu 50\% : Air 50\%), A2 (madu 60\% : Air 40\%), dan A3 (madu 70\%: air 30\%) menuju kearah kental.

Perbedaan perlakuan dari perbandingan madu dan air tidak berbeda nyata terhadap parameter aroma sirup limbah sari mengkudu. Berdasarkan uji lanjut man whitney diketahui bahwa tingkat kesukaan panelis terhadap aroma sirup limbah sari mengkudu pada perlakuan A1 (madu 50\% : Air 50\%) tidak berbeda nyata dengan perlakuan A2 (madu 60\% : Air 40\%), dan A3 (madu 70\% : air 30\%). Tingkat kesukaan A1 (madu 50\% : Air 50\%) yaitu 4,67 (netral), tingkat kesukaan A2 (madu 60\% : Air 40\%) yaitu 4,83 (netral), dan tingkat kesukaan A3 (madu 70\% : Air 30\%) yaitu 4,83 (netral).

Faktor yang mempengaruhi kekentalan sirup hasil samping sari mengkudu adalah penambahan madu. Semakin banyak penambahan madu, semakin besar kekentalan yang dihasilkan. Hasil penilaian mutu dan tingkat kesukaan panelis terhadap ketiga sampel tidak terlalu jauh hal ini dikarenakan sirup yang dihasilkan tidak berbeda jauh penambahan madunya, sehingga kekentalan sirup secara visual tidak terlalu terlihat.

\section{Uji Fisik (Uji Kekentalan atau Viskositas)}

Berdasarkan hasil yang diperoleh dari pengukuran kekentalan dengan viscometer Brookfield (Lampiran 11), dapat dilihat kekentalan yang paling besar ditunjukkan pada sampel sirup limbah sari buah mengkudu dengan penambahan madu 70\% yaitu 11,50 cP. Sirup limbah sari buah mengkudu dengan penambahan madu 50\% memiliki nilai kekentalan 7,00 cP, dan sirup limbah sari buah mengkudu dengan penambahan madu $60 \%$ memiliki nilai kekentalan 11,00 cP. Semakin banyak penambahan madu, semakin besar kekentalan yang dihasilkan. Hal ini karena madu merupakan cairan yang kental (Apriyani, 2013). Kekentalan madu dipengaruhi oleh kadar air yang dikandung oleh madu tersebut. Jika kadar airnya tinggi, maka minuman sirup akan menjadi kurang kental.

\section{Produk Terpilih}

Berdasarkan hasil prosentase distribusi frekuensi pada Tabel 4, sirup yang terpilih adalah sirup yang memiliki nilai kesukaan organoleptik paling besar. Dari keempat parameter organoleptik yang diujikan pada sirup limbah sari buah mengkudu (rasa, aroma, warna dan kekentalan), diperoleh sirup limbah sari mengkudu dengan penambahan madu $70 \%$ memiliki nilai kesukaan maksimum pada parameter mutu rasa yaitu 4,38 (tidak terlalu asam),mutu aroma yaitu 4,80 (menuju tidak berbau) dan pada uji hedonik parameter rasa yaitu 5,23 (agak suka).

\section{Kandungan Kimia dan Mikroba Produk yang Terpilih}

Berdasarkan parameter organoleptik dengan uji hedonik diperoleh sirup limbah sari buah mengkudu terpilih adalah sirup dengan penambahan madu 70\%. Selanjutnya sirup 
terpilih ini dilakukan analisis kimia yaitu analisa antioksidan dan vitamin $\mathrm{C}$ yang terkandung di dalam sirup limbah sari buah mengkudu. Hasil analisa kimia dapat dilihat pada Tabel 4 .

Tabel 4 Hasil Analisa uji kimia (antioksidan dan vitamin C) dan uji mikroba (Total Plate Count)

\begin{tabular}{lrc}
\hline \multicolumn{1}{c}{ Parameter } & Hasil Uji & Satuan \\
\hline Antioksidan & 859 & IC50 (ppm) \\
Vitamin C & 15,53 & $\%$ \\
Total Plate & 175 & CFU $/ \mathrm{mL}$ \\
Count & & \\
\hline
\end{tabular}

\section{Pengujian Antioksidan}

Berdasarkan hasil uji yang didapatkan, dapat dilihat pada Tabel 6 bahwa antioksidan di dalam sirup limbah sari buah mengkudu adalah 859 IC50 (ppm). Hal ini menunjukkan jumlah antioksidan didalam sirup limbah sari buah mengkudu sangat lemah tetapi masih terdapat antioksidan didalam sirup limbah sari buah mengkudu tersebut. Jumlah antioksidan yang kecil di dalam sirup limbah sari buah mengkudu dapat disebabkan oleh penambahan air karena semakin tinggi pengenceran senyawa antioksidan yang ada akan semakin sedikit dan dapat disebabkan oleh proses pemanasan, proses pemanasan yang dilakukan mempengaruhi kestabilan aktivitas antioksidan yang terkandung didalam sirup (Rakhmawati dan Yunianta, 2015).

\section{Analisis Vitamin C}

Berdasarkan hasil analisis vitamin C pada sirup limbah sari buah mengkudu diperoleh hasil 15,53\%. Vitamin C yang dihasilkan sirup limbah sari mengkudu relativ kecil, hal ini dapat disebabkan vitamin $\mathrm{C}$ yang terdapat pada limbah sari buah mengkudu berkurang pada saat proses pengolahan. Seperti pada saat pencucian karena vitamin $\mathrm{C}$ mudah larut dalam air, atau saat perebusan vitamin $\mathrm{C}$ menjadi rusak.

\section{Pengujian Mikroba (Total Plate Count)}

Berdasarkan hasil uji yang di dapatkan, dapat dilihat pada tabel 6 bahwa Total Plate Count di dalam sirup limbah sari buah mengkudu adalah $175 \mathrm{CFU} / \mathrm{mL}$. Syarat umum sirup berdasarkan SNI 3544:2013 Total Plate Count adalah maksimum $500 \mathrm{CFU} /$ gram atau $\mathrm{CFU} / \mathrm{mL}$. Hasil yang didapatkan masih memenuhi standar SNI sirup pada umumnya.

\section{KESIMPULAN DAN IMPLIKASI}

Berdasarkan hasil penelitian yang dilakukan sirup limbah sari buah mengkudu yang terpilih berdasarkan tingkat kesukaan panelis adalah sirup dengan penambahan madu 70\% yang memiliki nilai kekentalan (viskositas) yaitu 11,50 cP. Kandungan kimia produk sirup limbah sari buah mengkuduaktivitas antioksidan sebesar859 IC50 (ppm) dan kandungan vitamin C sebesar 15,53\%. Kandungan mikroba yaitu Total Plate Count didalam sirup limbah sari mengkudu sebesar $175 \mathrm{CFU} / \mathrm{mL}$. Perlu dilakukan penelitian lebih lanjut bagaimana meningkatkan efektivitas antioksidan dan vitamin $\mathrm{C}$ didalam sirup limbah sari buah mengkudu yang lebih tinggi.

\section{DAFTAR PUSTAKA}

Andriana M., Scheling W., dan Nyoman A.. 2004. Pengaruh fermentasi terhadap ketajaman aroma jus mengkudu (Morinda citrifolia L.). Jurnal Ilmu dan Teknologi Pangan 2 (1) : 33 - 39.

Apriani D., Gusnedi, dan Yanni D. 2013. Studi tentang nilai viskositas madu hutan dari beberapa daerah di sumatera barat untuk mengetahui kualitas madu. Jurnal Pillar of Physics 2 : 91-98.

Ariesta T.A. 2012. Proses Produksi Pembuatan Sirup Belimbing Manis [laporan tugas akhir]. Fakultas Pertanian, Universitas Sebelas Maret, Surakarta.

Bijanti R. 2008. Potensi sari buah mengkudu (Morinda citrifolia L.) terhadap kualitas karkas, kadar vitamin C dan kadar malonedialdehide (mda) dalam darah ayam pedaging. Jurnal MediaKedokteran Hewan $24(1): 43-48$. 
Bintang I.A.K., A.P. Sinurat.dan T. Purwadaria. 2007. Penambahan ampas mengkudu sebagai senyawa bioaktif terhadap performans ayam broiler. Jurnal JITV 12 (1) $: 1-5$.

Cahyadi W. 2006. Analisis dan Aspek Kesehatan Bahan Tambahan Pangan. Bumi Aksara, Jakarta.

Fitriani S. dan Evi S. 2009. Pengembangan formulasi sirup berbahan baku kulit dan buah nanas (Ananas Comosus L. Merr). Jurnal Laboratorium Pengolahan Hasil Pertanian Fakultas Pertanian Universitas Riau 8 (1) : 34 - 39.

Nurhasannah dan Anton R. 2014. Modul Praktikum Analisis Pangan. Politeknik Akademi Kimia Analisis Bogor, Bogor.

Hardoko, Adolf P., dan Ivonne P. 2003. Mempelajari Karakteristik Sari Buah dari Mengkudu (Morinda Citrifolia L.) yang dihasilkan Melalui Fermentasi. Jurnal Teknol dan Industri Pangan XIV (2) : 144 153.

Institute Pertanian Bogor. 1991. Penelitian dan pengembangan teknologi pangan. Jurnal Buletin Pusbangtepa LP IPB 9 no.20 : $17-28$.

Laili M., Alimuddin, dan Erwin. 2017. Penetapan kadar vitamin c dalam sirup buah naga merah (Hylocereus Polyrhizus) dengan variasi waktu penyimpanan. Jurnal Atomik 02 (1) : 128-133.

Mayasari R. 2015. Kajian Karakteristik Biskuit Yang Dipengaruhi Perbandingan Tepung Ubi Jalar (Ipomea batatas L.) Dan Tepung Kacang Merah (Phaseolus vulgaris L.) [Skripsi]. Program Studi Teknologi Pangan, Fakultas Teknik, Universitas Pasundan, Bandung.

Mar'atirrosyidah R. dan Teti E,. 2015. Aktivitas antioksidan senyawa umbiumbian lokal inferior. Jurnal Pangan dan Agroindustri 3 (2) : 594-601.

Paju N., Paulina V.Y.Y., dan Novel K. 2013. uji efektivitas salep ekstrak daun binahong (Anredera cordifolia (Ten.) Steenis) pada kelinci (Oryctolagus cuniculus) yang terinfeksi bakteri Staphylococcus aureus. 1(2): 2302-2493.

Permatadini D. P. 2016. Substitusi Tepung Terigu dengan Tepung Singkong Modifikasi
(Modified Cassava Flour) pada Produk Soes Kering. Skripsi. Fakultas Ilmu Pangan Halal, Universitas Djuanda Bogor,Bogor.

Putri, R. K. 2016. Analisis Fisika dan Kimia Produk Sorbet Setengah Jadi di PT. Indolakto Ice Cream Manufacturing [laporan tugas akhir]. Politeknik Akademi Kimia Analisis Bogor, Bogor.

Raharja S., Imam P., dan Fitria Y. 2004. Ekstraksi dan analisa dietary fiber dari buah mengkudu (Morinda Citrifolia). Jurnal Teknik Industri Pertanian 14 (1): 30 - 39.

Rahmawati, A. Muflihunna, dan Laode M. S. 2016. Analisis aktivitas antioksidan produk sirup buah mengkudu (Morinda Citrifolia L.) dengan metode DPPH. Jurnal Fitofarmaka Indonesia 2(2) : 97 - 101.

Rakhmawati R. dan Yunianta. 2015. Pengaruh proporsi buah : air dan lama pemanasan terhadap aktivitas antioksidan sari buah kedondong (Spondias Dulcis). Jurnal Pangan dan Agroindustri 3 (4) : 1682 1693.

Rohman A., Sugeng R., dan Nurul K.H.. 2007. Aktivitas antioksidan, kandungan fenolik total, dan flavonoid total daun mengkudu. Agritech 27 (4) : 147 -151.

Sadeli R. A. 2016. Uji Aktivitas Antioksidan Dengan Metode DPPH (1,1-Diphenyl-2Picrylhydrazyl) Ekstrak Bromelain Buah Nanas (Ananas Comosus (L.) Merr.) [skripsi]. Fakultas Farmasi, Universitas Sanata Dharma, Yogyakarta.

Setyaningsih. 2010. Analisis Sensori Untuk Industri Pangan dan Agro. Departemen Ilmu dan teknologi Pangan [skripsi]. Fakultas Teknologi Pertanian, Institut Pertanian Bogor, Bogor.

[BSN] Badan Standarisasi Nasional. 1992. SNI 19-2897-1992tentang Cara Uji Cemaran Mikroba. Badan Standarisasi Nasional, Indonesia.

Suhartono E., Bambang S., Edyson, dan Ramlah. 2005. Uji aktivitas antioksidan jus buah mengkudu (Morinda Citrifolia) dan perannya sebagai inhibitor Advanced Glycation end products (AGEs) akibat reaksi glikosilasi. Jurnal Ilmu Kedokteran 37(1) : 1-6.

Untsa Uzlifah. 2014. Aktivitas Antioksidan Sirup Kombinasi Daun Sirsak (Annona 
Muricata) dan Kulit Buah Naga (Hylocereus Costaricensis) dengan Variasi Lama Perebusan [Naskah Publikasi]. Fakultas Keguruan dan Ilmu

Pendidikan, Universitas Muhammadiyah Surakarta, Surakarta.

Waha, M.G. 2002. Sehat dengan Mengkudu. REN Media. Jakarta.

Werdhasari, A. 2014. Peran antioksidan bagi kesehatan. Jurnal Biotek Medisiana Indonesia3 (2) : 59-68.
Winarno, F. G., 1992. Kimia Pangan dan Gizi. PT Gramedia Pustaka Utama. Jakarta.

Winarno F.G. 2008. Kimia Pangan Dan Gizi. Mbrio Press, Bogor.

Winarsih H. 2007. Antioksidan Alami dan Radikal Bebas (5nd ed.). Kanisius. Yogyakarta.

Winarti, C. 2005. Peluang pengembangan minuman fungsional dari buah mengkudu (Morinda Citrifolia L.). Jurnal Litbang Pertanian 24(4) : 149-155. 